\title{
Physiological responses of Eucalyptus $x$ urograndis to glyphosate are dependent on the genotype
}

\author{
Respostas fisiológicas de Eucalyptus x urograndis ao \\ glyphosate são dependentes do genótipo
}

\author{
Leonardo Bianco de Carvalho1, Stephen Oscar Duke² and Pedro Luis da Costa Aguiar Alves ${ }^{3}$
}

\section{Resumo}

Experimentos foram conduzidos em câmara de crescimento com objetivo de avaliar o impacto de glyphosate em trocas gasosas de genótipos de Eucalyptus $x$ urograndis e verificar se alterações em algumas características metabólicas e anatômicas poderiam estar relacionadas com respostas distintas das plantas. No primeiro experimento, os tratamentos consistiram de seis doses de glyphosate (variando de 18 até $720 \mathrm{~g} \mathrm{ae} \mathrm{ha}^{-1}$ ) e dois genótipos de eucalipto, além de testemunha sem aplicação do herbicida para cada genótipo. Avaliou-se taxa de assimilação de $\mathrm{CO}_{2}$, taxa de transpiração, condutância estomática $(1,2,4 \mathrm{e}$ 7 dias após tratamento - DAT), espessura foliar e índice estomático (30 DAT). No segundo experimento, os tratamentos consistiram da aplicação de glyphosate na dose de $180 \mathrm{~g}^{2}$ ae ha-1 nos mesmos genótipos, também mantendo testemunha sem aplicação para cada genótipo. Avaliou-se os teores foliares de glyphosate, ácido aminometilfosfônico e ácido chiquímico em 1, 2, 4, and 7 DAT. À medida que se aumentou a dose de glyphosate (18 até $720 \mathrm{~g}_{\text {ea ha-1 }}{ }^{-1}$ ), a taxa de assimilação de $\mathrm{CO}_{2}$, a taxa de transpiração e a condutância estomática decresceram mais rápida e intensamente no genótipo GG100 (31\%) comparado ao genótipo C219 (22\%). Ácido chiquímico acumulou em ambos os genótipos, com níveis mais altos no genótipo GG100 (5 vezes mais), em 1 e 2 dias após aplicação de glyphosate em dose única de $180 \mathrm{~g} \mathrm{ea} \mathrm{ha}^{-1}$. Não ocorreram diferenças significativas entre os genótipos quanto a teor de glyphosate, espessura foliar e índice estomático. Ácido aminometilfosfônico não foi detectado. A redução nas trocas gasosas devido à exposição ao glyphosate é dependente do genótipo de eucalipto, podendo ser explicada, em parte, pelo acúmulo diferencial de ácido chiquímico, mas provavelmente não está relacionada com espessura foliar, índice estomático e absorção ou degradação de glyphosate.

Palavras-chave: Eucalipto, trocas gasosas, ácido chiquímico, herbicida.

\begin{abstract}
Experiments were conducted in a growth chamber aiming to evaluate glyphosate impacts on gas exchange of two Eucalyptus $x$ urograndis genotypes and to verify whether alterations in some metabolic and anatomical characteristics could be related to different plant responses. In a first experiment, treatments consisted of six doses of glyphosate (range from 18 up to $720 \mathrm{~g}$ ae ha-1) and two eucalyptus genotypes ( $\mathrm{C} 219$ and $\mathrm{GG} 100$ ), plus a herbicide-free control for each genotype. $\mathrm{CO}_{2}$ assimilation rate, transpiration rate, stomatal conductance $(1,2,4$, and 7 days after treatment - DAT), leaf thickness and stomatal index (30 DAT) were evaluated. In a second experiment; treatments consisted of applying glyphosate at $180 \mathrm{~g}$ ae $\mathrm{ha}^{-1}$ to the same genotypes, also maintaining a herbicide-free control for each genotype. We evaluated leaf contents of glyphosate, amino-methyl-phosphonic acid (AMPA), and shikimic acid at 1, 2, 4, and 7 DAT. As glyphosate dose increased (18 up to $720 \mathrm{~g}$ ae ha- $^{-1}$ ), $\mathrm{CO}_{2}$ assimilation rate, transpiration rate, and stomatal conductance decreased fastest and strongest in the GG100 (31\%) compared to the C219 genotype $(22 \%)$. Shikimic acid accumulated in both genotypes, with the highest levels in the GG100 genotype (5 times greater), at 1 and 2 days after spraying glyphosate at a single dose of $180 \mathrm{~g}$ ae ha-1. No significant differences occurred between genotypes in glyphosate content, leaf thickness, and stomatal index. AMPA was not detected in either genotype. Gas exchange alteration due to glyphosate exposure is dependent on eucalyptus genotype, and it may be in part explained by a differential accumulation of shikimic acid, but it probably does not relate to leaf thickness, number of stomata, and glyphosate absorption or degradation.
\end{abstract}

Keywords: Eucalyptus, $\mathrm{N}$-(phosphonomethyl)glycine, gas exchange, shikimic acid.

1PhD Professor. Unesp - Universidade Estadual Paulista Júlio de Mesquita Filho. Access way Prof. Paulo Donato Castellane, s/n - 14884900 - Jaboticabal, SP, Brasil. E-mail: leonardo.carvalho@unesp.br.

2Research Leader. United States Department of Agriculture / NPURU - Natural Product Utilization Research Unit - 38677 - Universitiy, MS, USA. Email: stephen.duke@ars.usda.fova.

${ }_{3}^{3}$ hD Professor. Unesp - Universidade Estadual Paulista Júlio de Mesquita Filho. Access way Prof. Paulo Donato Castellane, s/n - 14884900 - Jaboticabal, SP, Brasil. E-mail: plalves@fcav.unesp.br.

Sci. For., Piracicaba, v. 46, n. 118, p. 177-187, jun. 2018 DOI: dx.doi.org/10.18671/scifor.v46n118.04 


\section{INTRODUCTION}

Glyphosate [ $N$-(phosphonomethyl)-glycine ] is the most important herbicide in history (DUKE; POWLES, 2008). It is used extensively for weed management in glyphosate-resistant crops, as well as in many other cropping situations, including woody crops such as eucalyptus (Eucalyptus spp.) (CARVALHO et al., 2016). Because glyphosate is a non-selective, broad-spectrum herbicide, it has the potential to cause injury to any plant species that is not tolerant and has not either been engineered for glyphosate resistance or evolved resistance to glyphosate. The biggest problem of the use of this herbicide in eucalyptus plantations is accidental drift, whose symptoms of phytotoxicity may be observed in young plants and sprouts of eucalyptus under field conditions (TUFFI SANTOS et al., 2005; SALGADO et al., 2017). Even though glyphosate is used with eucalyptus, it can either stimulate growth or cause damage, depending on the use rate (VELINI et al., 2008; NASCENTES et al., 2018).

The herbicide glyphosate inhibits the enzyme 5-enolpyruvyl-shikimate-3-phosphate synthase (EPSPS) of the shikimate pathway (DUKE; POWLES, 2008), and it results in massive carbon flow to shikimate-3-phosphate, converting into high levels of shikimic acid (DUKE, 1988).Thus, high levels of shikimic acid are rapidly accumulated in glyphosate-treated plants (STEINRUCKEN; AMRHEIN, 1980). As a result, treated plants show insufficient aromatic amino acid production to maintain necessary protein and shortages of carbon for other essential pathways (SIEHL, 1997). In addition, there are reports of glyphosate impacting on photosynthetic (GEIGER et al., 1987; PEREIRA et al., 2010; CARVALHO et al., 2014) and morpho-anatomical characteristics of treated plants (TUFFI SANTOS et al., 2005; TUFFI SANTOS et al., 2009). However, the mechanisms involved in the alteration of gas exchange after glyphosate exposure still remain unclear.

Glyphosate is a post-emergent herbicide absorbed by plants through leaves and other green tissues, and it translocates via phloem into meristematic tissues (DUKE; POWLES, 2008), especially in susceptible plants. Less sensitive plants may occur due to sequestration of glyphosate into vacuoles, limiting glyphosate translocation, although enhanced vacuolar sequestration has only been shown to occur in some species with evolved resistance to glyphosate (e.g., GE et al., 2010, 2012). Greater rates of glyphosate degradation into non-toxic compounds (CRUZ-HIPOLITO et al., 2009; ROJANO-DELGADO et al., 2010) may play a role in some cases of glyphosate tolerance, but this mechanism has not been clearly shown to be involved in evolved resistance. Glyphosate degradation in most plants is by conversion to aminomethylphosphonic acid (AMPA) and glyoxylate (DUKE, 2011). AMPA is a very weak phytotoxin, and glyoxylate is not toxic to plants. The mechansism(s) of natural tolerance to glyphosate of some species and biotypes is poorly understood (e.g., RIBEIRO et al., 2015).

In previous studies with eucalyptus, Carvalho et al. (2015) found different initial growth among four genotypes exposed to glyphosate, but they did not study the mechanism involved in the differential plant susceptibility. Chlorophyll content and chlorophyll $a$ fluorescence can be used to study direct and indirect effects of herbicides on photosynthesis (JUNEAU et al., 2007). Carvalho et al. (2016) found no differences between genotypes in either chlorophyll content or the Fv/Fm (the ratio between variable and maximum chlorophyll fluorescence), indicating that differences in eucalyptus growth may not be explained by a significant impact of glyphosate on a light reaction of photosynthesis. In these studies, the same eucalyptus genotypes were used as in the present study. Thus, we supposed differential eucalyptus growth could be caused by some different impact on the dark reaction of photosynthesis.

The objective of this paper was to test whether glyphosate differentially impacts gas exchange of two eucalyptus genotypes in order to verify whether some metabolic and/or anatomical characteristics could contribute to different genotype responses.

\section{MATERIAL AND METHODS}

\section{Plant material and growing conditions}

Eucalyptus x urograndis plantlets (hereafter designed as C219 and GG100) were obtained from vegetative propagation in a commercial clonal mini-garden. They were planted into 3-L pots filled with a mixture of organic substrate and washed river sand in a proportion of 1:1 (v:v). Pots were daily irrigated with $100 \mathrm{~mL}$ of 50\% concentration of Hoagland and Arnon (1950) nutrient solution. Plants 
were grown in a growth chamber at a temperature of $25 \pm 2{ }^{\circ} \mathrm{C}$, a photoperiod of $14: 10 \mathrm{~h}$ (light:dark), and photosynthetically active radiation of $400 \mu \mathrm{mol} \mathrm{m}^{-2} \mathrm{~s}^{-1}$ delivered by white fluorescent lights.

\section{Experiment 1 - Gas exchange, leaf thickness, and stomatal index}

In the first experiment, we studied gas exchange, leaf thickness, and stomatal index of eucalyptus genotypes exposed to glyphosate (isopropyl-amine salt formulation). Treatments consisted of a factorial scheme $2 \times 7$ (two eucalyptus genotypes and six glyphosate doses with a herbicide-free control for each clone), arranged in a completely randomized design with six replicates. Glyphosate was sprayed at doses of $18,36,72,180,360$, and $720 \mathrm{~g}$ of acid equivalent per hectare ( $\mathrm{g}$ ae ha $\mathrm{h}^{-1}$ ) directly onto the eucalyptus shoots by using a $\mathrm{CO}_{2}$ backpack-sprayer equipped with four flat fan nozzles (110:02 model) at 2 bars pressure and $200 \mathrm{~L} \mathrm{ha}^{-1}$ spray volume. Water was sprayed to the non-treated control plants $(0 \mathrm{~g}$ ae ha-1). Spraying was performed at $50 \mathrm{~cm}$ above the top of plants, after which eucalyptus plantlets were kept for a 10-day acclimation period within the growth chamber. At the time of spraying, the plants were 120 days-old, with 6 leaves, and were $\sim 30 \mathrm{~cm}$-tall.

Gas exchange ( $\mathrm{CO}_{2}$ assimilation rate, transpiration rate, and stomatal conductance) was measured with an infra-red gas analyzer using $900 \mu \mathrm{mol} \mathrm{m} \mathrm{m}^{-2} \mathrm{~s}^{-1}$ of photosynthetic active radiation at $25^{\circ} \mathrm{C}$ leaf temperature. Measurements were performed on the second expanded-leaf from the top at 1, 2, 4 , and 7 days after treatment with glyphosate (DAT).

Leaf thickness was determined at 30 DAT using the methods of Johansen (1940) and Krauter (1985). We prepared semi-permanent slides from leaf samples, previously fixed in FAA 50 (50 mL of $37 \%$ formaldehyde $+50 \mathrm{~mL}$ of $100 \%$ acetic acid $+900 \mathrm{~mL}$ of $50 \%$ ethanol), and proceeded with transverse cuts onto the middle region of leaf blade. After that, images were captured using a digital camera (13 megapixels) coupled to an optical microscope, and then digitally analyzed. Leaf thickness was determined over the main vein and the leaf blade next to the main vein.

Stomatal index was determined at 30 DAT. In the middle region of the abaxial leaf surface, we counted the number of stomata and number of other epidermal cells, using an optical microscope equipped with an ocular reticle. Stomatal index was calculated by the following formula: S.I. = [number of stomata/(number of other epidermal cells + number of stomata)] (SALISBURY, 1927).

\section{Experiment 2 - Glyphosate, amino-methyl-phosphonic acid, and shikimic acid}

In the second experiment, we studied the content of glyphosate and AMPA, and the accumulation of shikimic acid in leaf tissues of the same eucalyptus genotypes exposed to glyphosate. General spraying conditions were similar to the first experiment, applying a dose providing general significant difference between genotypes in the first experiment (180 g ae ha' $\mathrm{of}^{-1}$ glyphosate) to similar eucalyptus plants as described above. In addition, water was sprayed with regards to the non-treated control $\left(0 \mathrm{~g} \mathrm{ae} \mathrm{ha}^{-1}\right)$. Treatments were arranged in a completely randomized design with 10 replicates.

Content of glyphosate, AMPA, and shikimic acid was determined with a high performance liquid chromatography and mass spectrometry system (LC-MS/MS), according to methodology published by Gomes et al. (2015). At 1, 2, 4, and 7 DAT, all leaves were gathered from the whole plantlet, immediately frozen at $-80^{\circ} \mathrm{C}$, and then maintained at $-20^{\circ} \mathrm{C}$ until lyophilization. Lyophilized plant material was powdered, and then $100 \mathrm{mg}$ of plant material was weighted for simultaneous extraction and determination of shikimic acid, glyphosate, and AMPA by LC-MS/MS. Accumulation of shikimic acid was calculated by the difference of the content of that metabolite in treated and non-treated plants.

\section{Statistical analysis}

Data were analyzed using ANOVA and non-linear regression (considering glyphosate doses as the independent variable), using the significance of $5 \%$ for probability of error.

\section{RESULTS AND DISCUSSION}

\section{Gas exchange}

As glyphosate dose increased, $\mathrm{CO}_{2}$ assimilation rate (Figure 1), transpiration rate (Figure 2), and stomatal conductance (Figure 3) decreased in both C219 and GG100 genotypes. Generally, the 
reduction of these parameters was fastest and strongest in the GG100 genotype, compared to the herbicide-free control. Mean gas exchange was reduced by 31\% and 22\% in the C219 and GG100 genotypes, respectively, due to glyphosate exposure. In addition, the difference in $\mathrm{CO}_{2}$ assimilation rate between the two clones increased with time after glyphosate treatment (especially at doses ranging from next to 180 up to $\left.360 \mathrm{~g} \mathrm{ae} \mathrm{ha}^{-1}\right)$. However, differences in transpiration rate and stomatal conductance decreased with time (especially at doses higher than $72 \mathrm{~g}$ ae ha ${ }^{-1}$ ). In addition, carbon assimilation in non-treated plants of both genotypes was similar (Figure 1), but the GG100 genotype had a higher transpiration rate and stomatal conductance than genotype C219 (Figures 2 and 3). This difference between the genotypes was the same after treatment with glyphosate, but the reduction of gas exchange was more intense in the GG100 genotype, especially at intermediate glyphosate doses (Figures 1, 2, and 3).
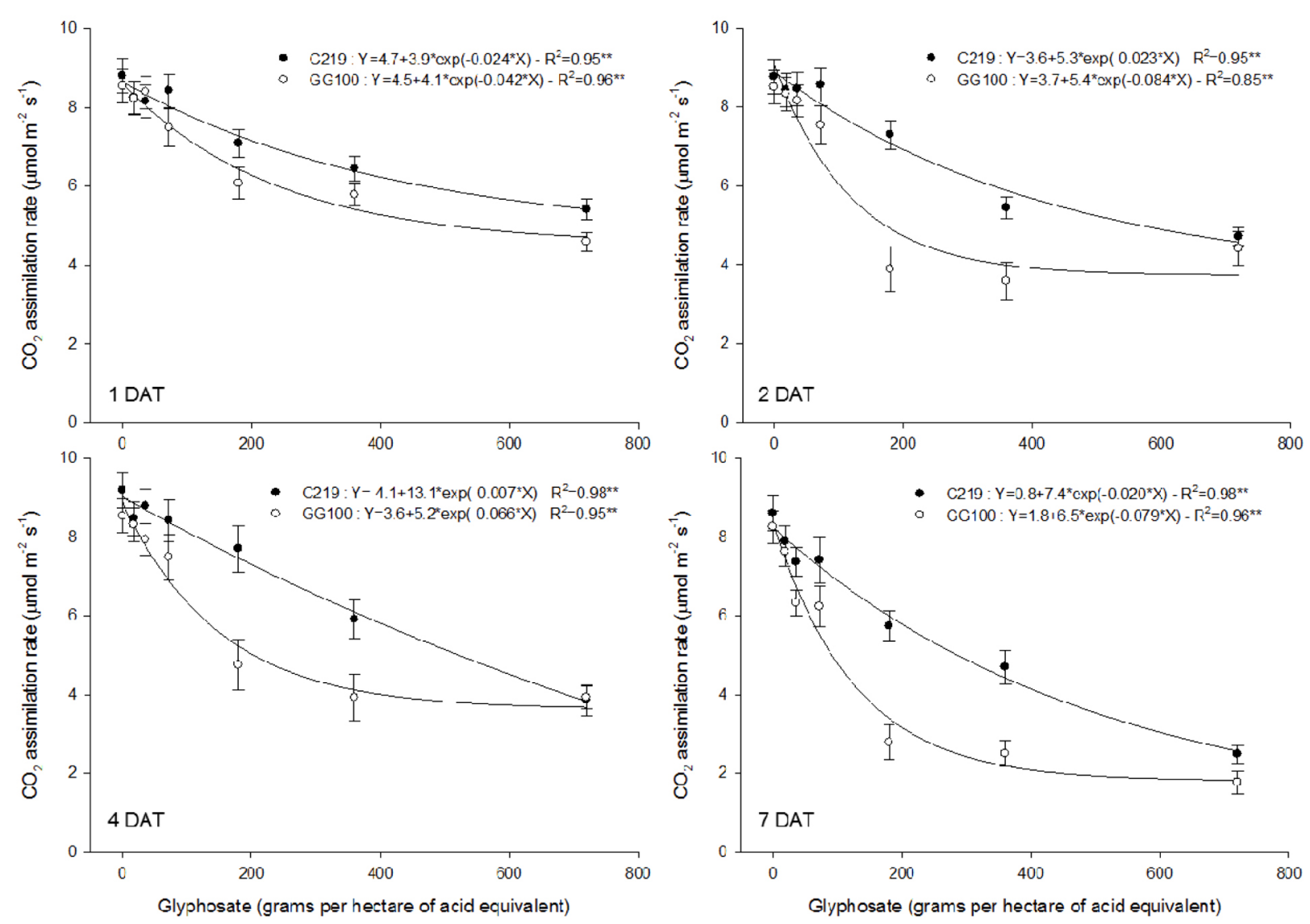

Figure 1. Rate of $\mathrm{CO}_{2}$ assimilation in Eucalyptus $x$ urograndis genotypes (C219 and GG100) at different days after treatment (DAT) with glyphosate. Vertical lines indicate standard error of mean.

Figura 1. Taxa de assimilação de $\mathrm{CO}_{2}$ em genótipos de Eucalyptus x urograndis (C219 e GG100) em diferentes dias após o tratamento (DAT) com glyphosate. Linhas verticais indicam o erro padrão da média.

Recently, an increase (in lower doses) or even a non-significant reduction (in higher doses) in $\mathrm{CO}_{2}$ assimilation rate, transpiration rate, and stomatal conductance was found in E. $x$ urograndis (the 144 genotype) treated with glyphosate at doses ranging from 1.8 up to $720 \mathrm{~g}$ a ha $^{-1}$ (NASCENTES et al., 2018). On the other hand, a reduced transpiration (22\%), as well as an increase (18\%) in stomatal resistance (inverse of stomatal conductance), was found in Eucalyptus grandis exposed to glyphosate at $120 \mathrm{~g}$ ae ha-1 $^{-1}$ at 7 DAT (PEREIRA et al., 2010), as observed in our study. The impact of glyphosate on transpiration rate and stomatal resistance occurs due to a metabolic imbalance caused by a disruption in the formation and maintenance of plant structures provided by an inhibition of the synthesis of aromatic amino acids (VIDAL, 1997). In addition, stomatal movement is the main mechanism of control of gas exchange in non-primitive plants (NASCENTES et al., 2018) and, as a consequence, decreased stomatal conductance has a disadvantageous impact on photosynthesis. Therefore, the reduced transpiration rate occurred due to the lower stomatal resistance found in glyphosate-treated plants, and it probably impacted on $\mathrm{CO}_{2}$ assimilation rate. However, it is clear that the level of this impact was dependent on the eucalyptus genotype. 

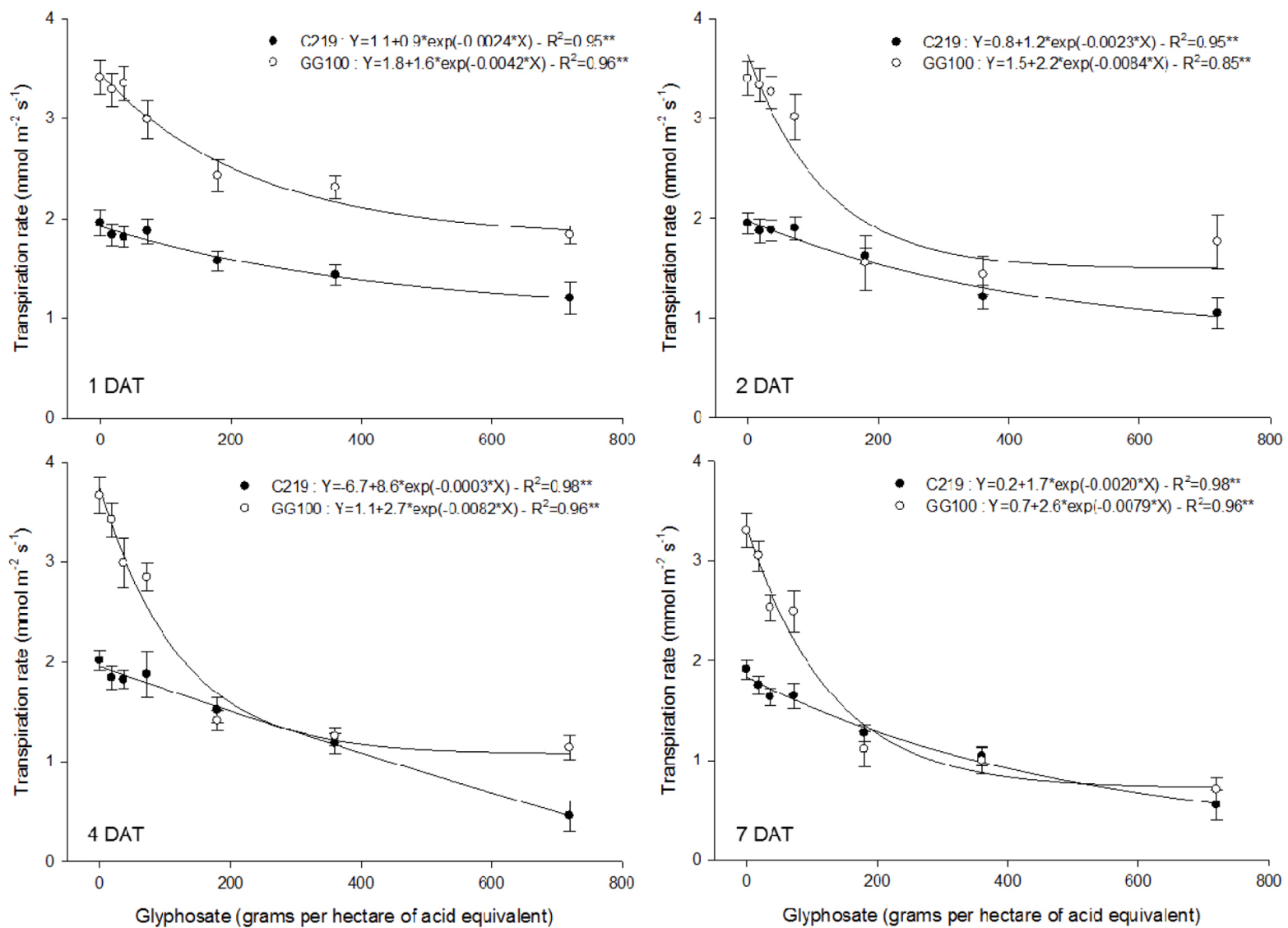

Figure 2. Rate of transpiration in Eucalyptus x urograndis genotypes (C219 and GG100) at different days after treatment (DAT) with glyphosate. Vertical lines indicate standard error of mean.

Figura 2. Taxa de transpiração em genótipos de Eucalyptus x urograndis (C219 e GG100) em diferentes dias após o tratamento (DAT) com glyphosate. Linhas verticais indicam o erro padrão da média.
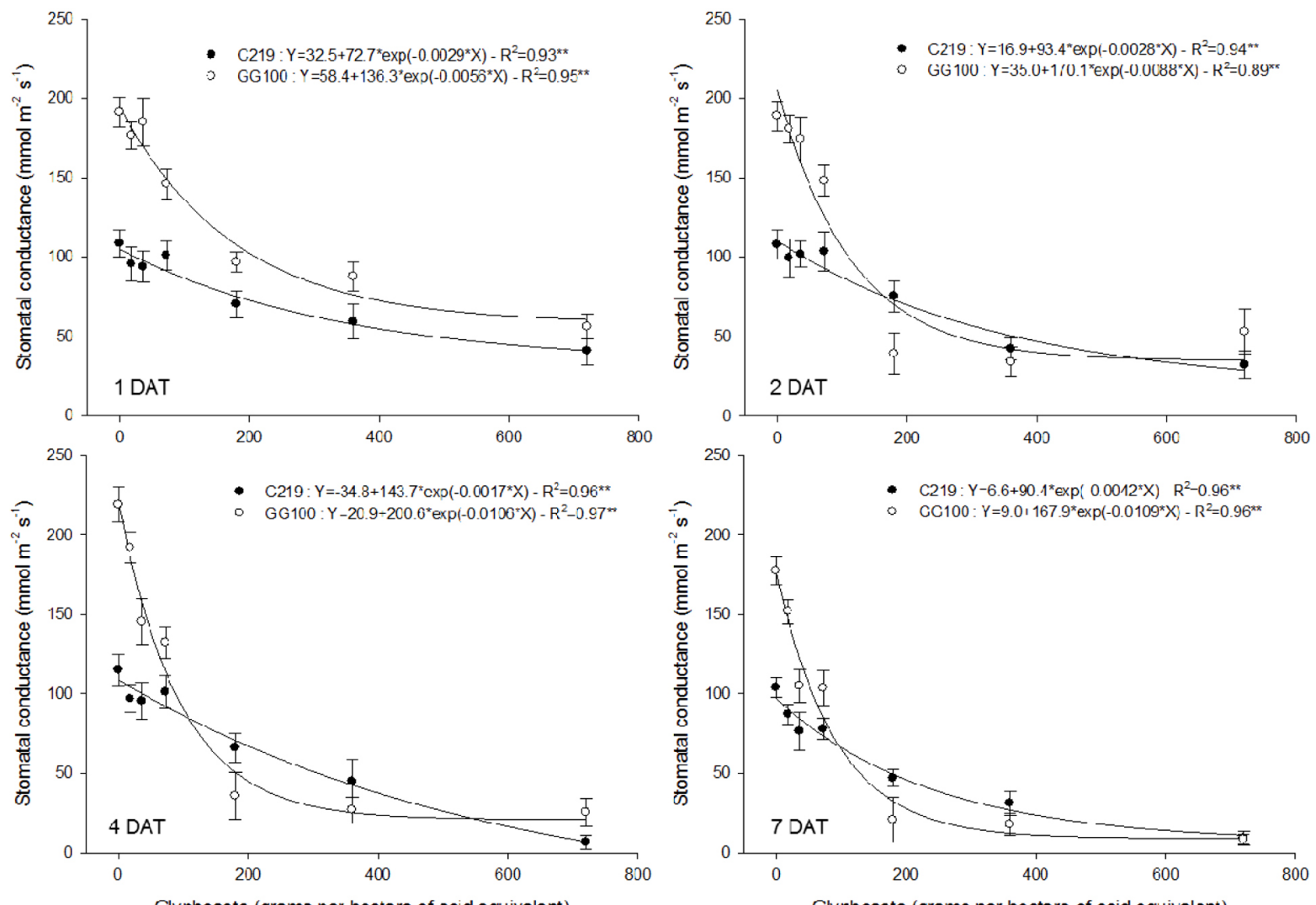

Figure 3. Stomatal conductance of Eucalyptus x urograndis genotypes (C219 and GG100) at different days after treatment (DAT) with a glyphosate isopropylamine salt herbicide. Vertical lines indicate standard error of mean.

Figura 3. Condutância estomática em genótipos de Eucalyptus x urograndis (C219 e GG100) em diferentes dias após o tratamento (DAT) com glyphosate. Linhas verticais indicam o erro padrão da média. 
The mechanism by which glyphosate affects photosynthesis is still not well understood. There are many indirect effects of glyphosate on photosynthesis, such as the inhibition of the biosynthesis of carotenoids, chlorophylls (FEDTKE; DUKE, 2005), and quinones (DEWICK, 1998), the disorganization of the photosynthetic apparatus (DE MARÍA et al., 2005), the decreased levels of the activity of the enzyme ribulose-1,5-biphosphate carboxylase/oxygenase (AHSAN et al., 2008), the degradation of chlorophylls (GOMES et al., 2016) and the accumulation of reactive oxygen species (MOLDES et al., 2008), causing disruption of proteins involved in photosynthesis (DIAZ VIVANCOS et al., 2011). These effects are likely to be secondary effects associated with a general decline in plant health due to inhibition of the shikimate pathway. The finding that carbon fixation is drastically inhibited within a short time after glyphosate treatment of sugar-beet leaves (GEIGER et al., 1987) and that such an effect is not accompanied by effects on chlorophyll fluorescence at the same time (OLESEN; CEDERGREEN, 2010), indicates that glyphosate more directly affects enzymatic carbon fixation than the light reactions of photosynthesis. Effects on chlorophyll fluorescence occur later, initially as subtle effects on the variable fluorescence curve because of blocked carbon fixation (MADSEN et al., 1995), and later as more drastic effects due to chloroplast deterioration (SILVA et al., 2014).

Glyphosate may also affect photosynthesis by modifying C metabolism in plants (GOMES et al., 2014). Decreases in net $C$ exchange and stomatal conductance were found after glyphosate application, culminating in reduction of $\mathrm{CO}_{2}$ assimilation capacity, leading to an increased intracellular concentration of $\mathrm{CO}_{2}$ (MATEOS-NARANJO et al., 2009; DING et al., 2011). Alteration in C metabolism caused by glyphosate may also relate with $\mathrm{C}$ flow into the shikimic pathway caused by a lack of regulation (GOMES et al., 2014), where inhibition of the shikimate pathway leads to an accumulation of shikimate-3-phosphate in the chloroplasts, becoming a C sink (SIEHL, 1997; DUKE; POWLES, 2008). Glyphosate may also impair C metabolism by interfering with sugar metabolism and translocation, as observed by Servaites et al. (1987) and Orcharay et al. (2012), resulting in an accumulation of soluble carbohydrates in leaves and roots of glyphosate-treated plants.

\section{Leaf thickness and stomatal index}

No significant glyphosate effect on leaf thickness (Figure 4) and stomatal index (Figure 5) occurred in either C219 or GG100 genotypes at 30 DAT. Therefore, the differential gas exchange of the two eucalyptus genotypes could not be explained by either leaf thickness or stomatal index. On the other hand, an increase in leaf thickness was observed in genotypes of $E$. $x$ urograndis (TUFFI SANTOS et al., 2005, 2009) and E. grandis and Eucalyptus urophylla (TUFFI SANTOS et al., 2009) at 15 days after spraying glyphosate at doses of $\sim 180 \mathrm{~g} \mathrm{ae} \mathrm{ha}^{-1}$, as a result of an expansion of palisade parenchyma cells. In addition, similar distribution and number of stomata was verified between genotypes of E. x urograndis, Eucalyptus grandis and Eucalyptus urophylla (TUFFI SANTOS et al., 2009). This supports the view that plant response to glyphosate exposure is dependent on the genotype.

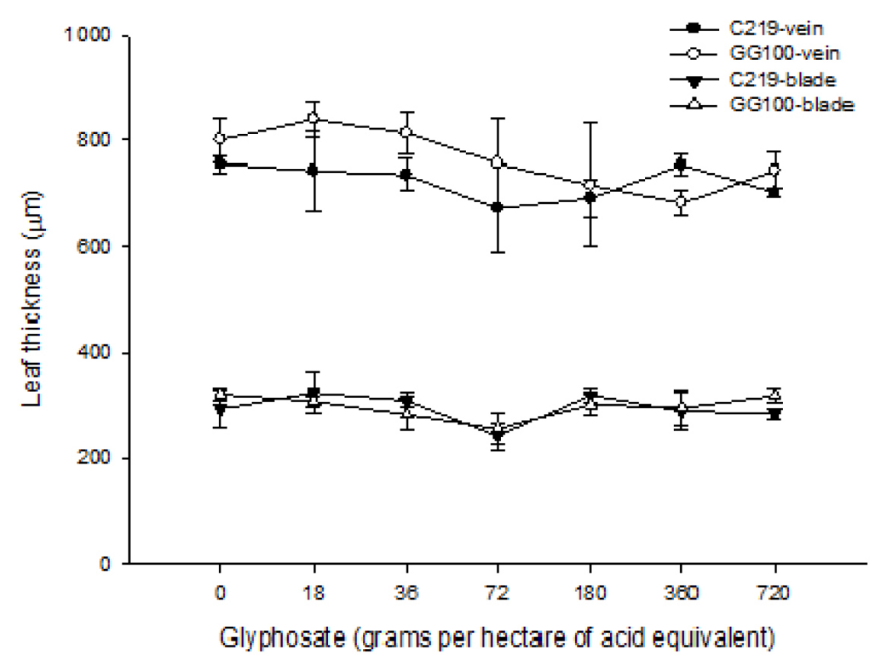

Figure 4. Leaf thickness of Eucalyptus x urograndis genotypes (C219 and GG100) at 30 days after treatment with a glyphosate iso-propyl-amine salt formulation. Vertical lines indicate standard error of mean.

Figura 4. Espessura foliar de Eucalyptus x urograndis (C219 e GG100) aos 30 dias após tratamento (DAT) com formulação de sal de isopropilamina de glyphosate. Linhas verticais indicam o erro padrão da média. 


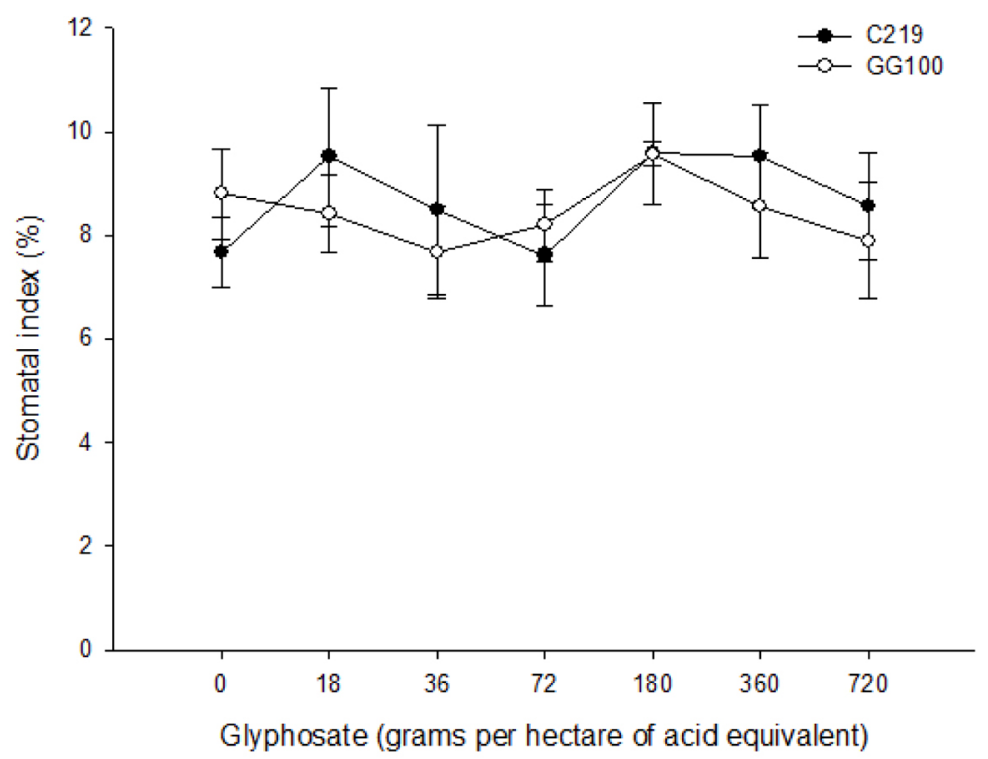

Figure 5. Stomatal index of Eucalyptus x urograndis genotypes (C219 and GG100) at 30 days after treatment with a glyphosate isopropylamine salt herbicide. Vertical lines indicate standard error of mean.

Figura 5. Índice estomático de Eucalyptus x urograndis (C219 e GG100) aos 30 dias após tratamento (DAT) com formulação de sal de isopropilamina de glyphosate. Linhas verticais indicam o erro padrão da média.

\section{Glyphosate and amino-methyl-phosphonic acid}

Content of glyphosate in leaf tissues of both C219 and GG100 genotypes increased with time, but no significant difference occurred between the two genotypes (Figure 6). In addition, AMPA was not detected in either genotype. As discussed by Carvalho et al. (2013), less absorption and greater capacity to detoxify glyphosate can be mechanisms involved in causing tolerance of plants to this herbicide. Therefore, differences found in photosynthetic response between genotypes could probably not be explained by glyphosate uptake or degradation. In addition, reduced translocation could explain the differential gas exchange observed in this study. However, the similar content of glyphosate found in leaves of both biotypes, does not support this idea. However, we did not evaluate the glyphosate content of stems or roots, so further studies should evaluate the pattern of glyphosate translocation in eucalyptus genotypes.

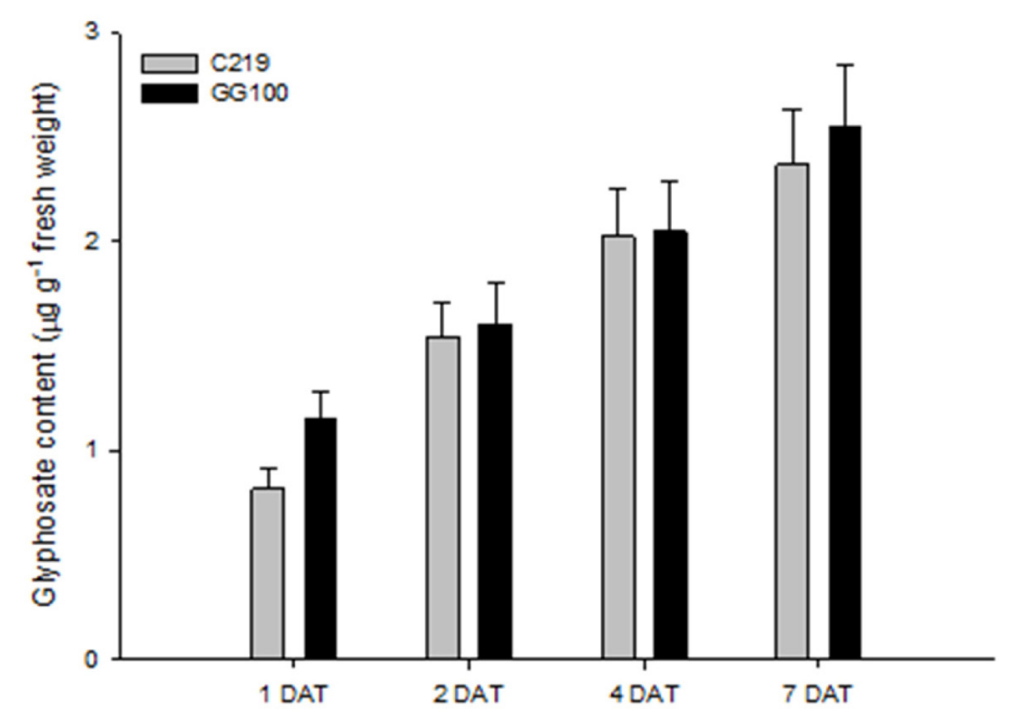

Figure 6. Content of glyphosate in leaf tissues of Eucalyptus $x$ urograndis genotypes (C219 and GG100) at different days after treatment (DAT) with 180 grams per hectare of acid equivalent of a glyphosate iso-propyl-amine salt formulation. Vertical lines indicate standard error of mean.

Figura 6. Concentração de glyphosate em tecidos foliares de genótipos de Eucalyptus x urograndis (C219 e GG100) em diferentes dias após o tratamento (DAT) com 180 gramas por hectare de equivalente ácido de formulação de sal de isopropilamina de glyphosate. Linhas verticais indicam o erro padrão da média. 


\section{Shikimic acid}

Shikimic acid increased with time (Figure 7), but GG100 accumulated more shikimic acid than C219 at 1 and 2 DAT (5-fold greater). Differential accumulation of shikimic acid indicates that the plant metabolism (especially the shikimate pathway) was affected more rapidly in the GG100 genotype. Some have speculated that inhibition of EPSPS causes deregulation of the shikimate pathway, leading to carbon fixation pathway intermediates being drained from C3 carbon fixation to the shikimate pathway to contribute to the high levels of shikimate that accumulate in glyphosate-treated plants (DUKE et al., 2003). Certain non-aromatic amino acid pools also increase after glyphosate treatment (MAROLI et al., 2016). The kinetics of inhibition of carbon assimilation and increases in shikimic acid of the two eucalyptus genotypes fit this explanation of the relationship between shikimic acid accumulation and inhibited carbon fixation. In addition, differences found in initial accumulation of shikimic acid (Figure 7) could in part explain the different gas exchange response to glyphosate observed between eucalyptus genotypes at 1 DAT and 2 DAT (Figure 1, 2, and 3).

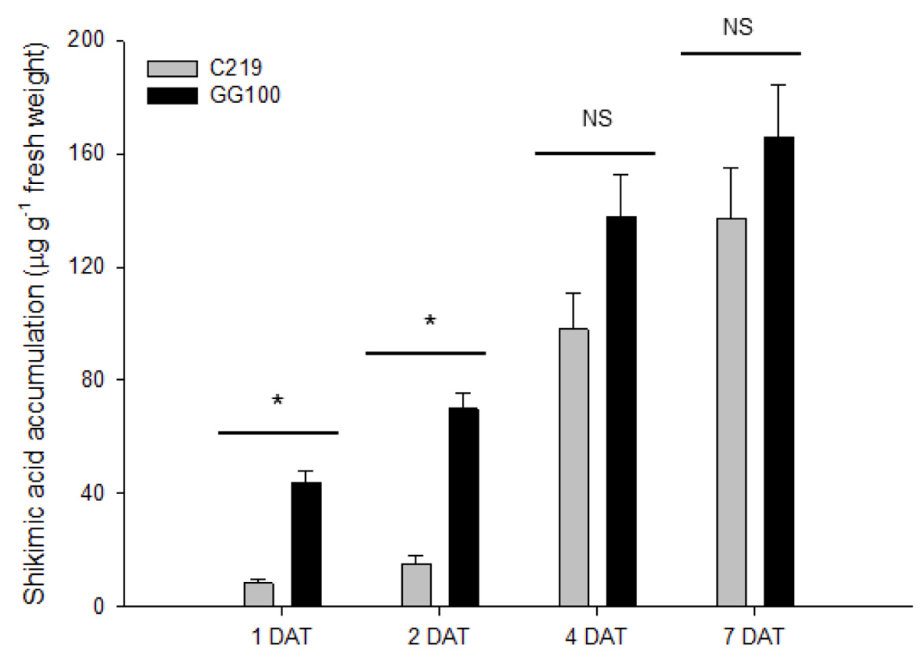

Figure 7. Accumulation of shikimic acid in leaf tissues of Eucalyptus x urograndis genotypes (C219 and GG100) at different days after treatment (DAT) with 180 grams per hectare of acid equivalent of a glyphosate iso-propyl-amine salt herbicide. Vertical lines indicate standard error of mean. * and NS indicate significant and no significant difference between genotypes at $5 \%$, respectively.

Figura 7. Acúmulo de ácido chiquímico em tecidos foliares de genótipos de Eucalyptus x urograndis (C219 e GG100) em diferentes dias após o tratamento (DAT) com 180 gramas por hectare de equivalente ácido de formulação de sal de isopropilamina de glyphosate. Linhas verticais indicam o erro padrão da média. * e NS indicam diferença significativa e não significativa entre genótipos a $5 \%$, respectivamente.

\section{CONCLUSION}

Gas exchange reduction due to glyphosate exposure is dependent on eucalyptus genotypes, but it does not occur due to differences in leaf thickness or number of stomata, and is probably not due to differential herbicide absorption or degradation. However, there are evidences that differential gas exchange is related to the level of shikimic acid accumulation.

\section{ACKNOWLEDGEMENTS}

Authors thank to professors Edivaldo D. Velini and Caio A. Carbonari for metabolic analysis and Fabiola V. Môro for anatomical analysis. Authors are also grateful to Fundação de Amparo à Pesquisa do Estado de São Paulo for the post-doc scholarship to the first author and to Conselho Nacional de Desenvolvimento Científico e Tecnológico for the current research scholarships to the first and the third authors.

\section{REFERENCES}

AHSAN, N.; LEE, D. G.; LEE, K. W.; ALAM, I.; LEE, S. H.; BAHK, J. D.; LEE, B. H. Glyphosate-induced oxidative stress in rice leaves revealed by proteomic approach. Plant Physiology and Biochemistry, v. 46, n. 12, p. 1062-1070, 2008. 
CARVALHO, L. B.; ALVES, P. L. C. A.; ANDRADE, T. C. G. R. Content and fluorescence of chlorophyll in eucalypt exposed to glyphosate. Communications in Plant Sciences, v. 6, n.1-2, p. 7-11, 2016.

CARVALHO, L. B.; ALVES, P. L. C. A.; COSTA, F. R. Differential response of clones of eucalypt to glyphosate. Revista Árvore, Viçosa, v. 39, n. 1, p.177-187, 2015.

CARVALHO, F. P.; FRANÇA, A. C.; SOUZA, B. P.; FIALHO, C. M. T.; SANTOS, J. B.; SILVA, A. A. Water use efficiency by Coffee arabica after glyphosate application. Acta Scientiarum Agronomy, Maringá. v. 36, n. 3, p. 373-377, 2014.

CARVALHO, L. B.; ALVES, P. L. C. A.; DUKE, S. O. Hormesis with glyphosate depends on coffee growth stage. Anais da Academia Brasileira de Ciências, Rio de Janeiro, v. 85, n. 2 p. 813-822, 2013.

CRUZ-HIPÓlITO, H.; OSUNA, M. D.; HEREDIA, A.; RUIZ-SANTAELLA, J. P.; DE PRADO, R. Non target mechanism involved in glyphosate tolerance found in Canavalia ensiformis plants. Journal of Agricultural and Food Chemiatry, v. 57, n. 11, p. 4844-4848, 2009.

DE MARÍA, N.; DE FELIPE, M. R.; FERNÁNDEZ-PASCUAL, M. Alterations induced by glyphosate on lupin photosynthetic apparatus and nodule ultrastructure and some oxygen diffusion related proteins. Plant Physiology and Biochemistry, v. 43, n. 10-11, p. 985-996, 2005.

DEWICK, P. M. The biosynthesis of shikimate metabolites. Natural Product Reports, London, v. 15, n. 1, p. $17-58,1998$.

DIAZ VIVANCOS P.; DRISCOLL S. P.; BULMAN C. A.; YING L.; EMAMI K.; TREUMANN A.; MAUVE, C.; NOCTOR, G.; FOYER, C. H. Perturbations of amino acid metabolism associated with glyphosate-dependent inhibition of shikimic acid metabolism affect cellular redox homeostasis and alter the abundance of proteins involved in photosynthesis and photorespiration. Plant Physiology, Bethesda, v. 157, n. 1, p. 256-268, 2011.

DING, W.; REDDY, K. N.; ZABLOTOWICZ, R. M.; BELLALOUI, N.; ARNOLD BRUNS, H. Physiological responses of glyphosate-resistant and glyphosatesensitive soybean to aminomethylphosphonic acid, a metabolite of glyphosate. Chemosphere, Oxford, v. 83, n. 4, p. 593-598, 2011.

DUKE, S. O. Glyphosate degradation in glyphosate-resistant and -susceptible crops and weeds. Journal of Agricultural and Food Chemistry, v. 59, n. 11, p. 5835-5841, 2011.

DUKE, S. O. Glyphosate. In: KEARNEY, P.C.; KAUFMAN, D.D. (Eds.). Herbicides: chemistry, degradation, and mode of action. Marcel Dekker: New York, 1988. v. 3, p. 1-70.

DUKE, S. O.; POWLES, S. B. Glyphosate: a once-in-a-century herbicide. Pest Management Science, v. 64, n. 4, p. 319-325, 2008.

DUKE, S. O.; BAERSON, S. R.; RIMANDO, A. M. Herbicides: glyphosate. In: PLIMMER, R.; GAMMON, D. W.; RAGSDALE, N. N. (Eds.). Encyclopedia of agrochemicals. New York: John Wiley \& Sons, 2003. p. 708-869.

FEDTKE, K.; DUKE, S. Herbicides. In: HOCK, B.; ELSTNER, E. (Eds.). Plant toxicology. New York: Marcel Dekker. 2005. p. 247-330.

GE, X.; D'AVIGNON, D. A.; ACKERMANA, J. J. H.; SAMMONS, R. D. Rapid vacuolar sequestration: the horseweed glyphosate resistance mechanism. Pest Management Science, v. 66, n. 4, p. 345-348, 2010.

GE, X.; D'AVIGNON, D. A.; ACKERMAN, J. J.; COLLAVO, A.; SATTIN, M.; OSTRANDER, E. L. HALL, E. L.; SAMMONS, R. D.; PRESTON, C. Vacuolar glyphosate-sequestration correlates with glyphosate resistance in ryegrass (Lolium spp.) from Australia, South America, and Europe: a 31P NMR investigation. Journal of Agricultural and Food Chemistry, v. 60, n. 5, p. 1243-1250, 2012.

Sci. For., Piracicaba, v. 46, n. 118, p. 177-187, jun. 2018 DOI: dx.doi.org/10.18671/scifor.v46n118.04 
Carvalho et al. - Physiological responses of Eucalyptus urograndis to glyphosate are dependent on the genotype

GEIGER, D. R.; TUCCI, M.A.; SERVAITES, J. C. Glyphosate effects on carbon assimilation and gas-exchange in sugar-beet leaves. Plant Physiology, Bethesda, v. 85, n. 2, p. 365-369, 1987.

GOMES, G. L. G. C.; CARBONARI, C. A.; VELINI, E. D.; TRINDADE, M. L. B.; SILVA, J. R. M. Extraction and simultaneous determination of glyphosate, AMPA and compounds of the shikimic acid pathway in plants. Planta Daninha, Viçosa, v. 33, n. 2, p. 295-304, 2015.

GOMES, M.P.;SMEDBOL, E.; CHALIFOUR, A.; HÉNAULT-ETHIER, L.; LABRECQUE, M.; LEPAGE, L.; LUCOTTE, M.; JUNEAU, P. Alteration of plant physiology by glyphosate and its by-product aminomethylphosphonic acid: an overview. Journal of Experimental Botany, Oxford, v. 65, n. 17, p. 4691-4703, 2014.

HOAGLAND, D.; ARNON, D. I. The water-culture method for growing plants without soil. California: AES, 1950. $32 \mathrm{p}$.

JOHANSEN, D. A. Plant microtechnique. New York: McGraw-Hill, 1940. 128 p.

JUNEAU, P.; QIU, B.; DEBLOIS, C. P. Use of chlorophyll fluorescence as a tool for determination of herbicide toxic effect: Review. Toxicological \& Environmental Chemistry, v. 89, n. 4, p. 609-625, 2007.

KRAUTER, D. Erfahrungen mit Etzolds FSA-Färbung für pflanzenschnitte. Mikrokosmos, v. 74, n. 8, p. 231233, 1985.

MADSEN, K. H.; HEITHOLT, J. J.; DUKE, S. O.; SMEDA, R. J.; STREIBIG, J. Photosynthetic parameters in glyphosate-treated sugarbeet (Beta vulgaris L.). Weed Research, Oxford, v. 35, n. 1, p. 81-88, 1995.

MAROLI, A. S.; NANDULA, V. K.; DUKE, S. O.; THARAYIL, N. Stable isotope resolved metabolomics reveals the role of anabolic and catabolic processes in glyphosate-induced amino acid accumulation in Amaranthus palmeri biotypes. Journal of Agricultural and Food Chemistry, v. 64, n. 37, p. 7040-7048, 2016.

MATEOS-NARANJO, E.; REDONDO-GÓMEZ, S.; COX, L.; CORNEJO, J.; FIGUEROA, M. E. Effectiveness of glyphosate and imazamox on the control of the invasive cordgrass Spartina densiflora. Ecotoxicology and Environmental Safety, v. 72, n. 6, p. 1694-1700, 2009.

MOLDES C. A.; MEDICI L. O.; ABRAHÃO O. S.; TSAI S. M.; AZEVEDO R. A. Biochemical responses of glyphosate resistant and susceptible soybean plants exposed to glyphosate. Acta Physiologiae Plantarum, v. 30, n. 4, p. 469-479, 2008.

NASCENTES, R. F.; CARBONARI, C. A.; SIMÕES, P. S.; BRUNELLI, M. C.; VELINI, E. D.; DUKE, S. O. Low doses of glyphosate enhance growth, $\mathrm{CO}_{2}$ assimilation, stomatal conductance and transpiration in sugarcane and eucalyptus. Pest Management Science, v. 74, n. 5, p. 1197-1205, 2018.

OLESEN, C. F.; CEDERGREEN, N. Glyphosate uncouple gas exchange and chlorophyll fluorescence. Pest Management Science, v. 66, n. 5, p. 536-543, 2010.

ORCHARAY, L.; ZULET, A.; ZABALZA, A.; ROYELA, M. Impairment of carbon metabolism induced by the herbicide glyphosate. Journal of Plant Physiology, v. 169, n. 1, p. 27-33, 2012.

PEREIRA, M. R. R.; RODRIGUES, A. C. P.; COSTA, N. V.; MARTINS, D.; KLAR, A. E.; SILVA, M. R. Efeito da deriva de glyphosate sobre algumas características fisiológicas Em plantas de eucalipto. Interciencia, Caracas, v. 35, n. 4, p. 279-283, 2010.

RIBEIRO, D. N.; NANDULA, V. K.; DAYAN, F. E.; RIMANDO, A. M.; DUKE, S. O.; REDDY, K. N.; SHAW, D. R. Possible glyphosate tolerance mechanism in pitted morningglory (Ipomoea lacunosa L.). Journal of Agricultural and Food Chemistry, v. 63, n. 8, p. 1689-1697, 2015. 
ROJANO-DELGADO, A. M.; RUIZ-JIMÉNEZ, J.; CASTRO, M. D. L.; DE PRADO, R. Determination of glyphosate and its metabolites in plant material by reversed-polarity $\mathrm{CE}$ with indirect absorptiometric detection. Electrophoresis, v. 31, n. 8, p. 1423-1430, 2010.

SALGADO, T. P.; PEREIRA, F. M. C.; KUVA, M. A.; ALVES, P. L. C. A. Effects of glyphosate on growth, yield and wood quality of Eucalyptus urograndis. Journal of Tropical Forest Science, Kepong, v. 29, n. 3, p. 257-266, 2017.

SALISBURY, E. J. On the causes and ecological significance of stomatal frequency, with special reference to the woodland flora. Philosophical Transactions, London, v. 216, n. 431-439, p.1-65, 1927.

SERVAITES, J. C.; TUCCI, M. A.; GEIGER, D. R. Glyphosate effects on carbon assimilation, ribulose bisphosphate carboxylase activity, and metabolite levels in sugar beet leaves. Plant Physiology, Bethesda, v. 85 , n. 2, p. 370-374, 1987.

SIEHL, D. L. Inhibitors of EPSP synthase, glutamine synthase and histidine synthesis. In: ROE, R. M.; BURTON, J. D.; KUHR, R.J. Herbicide activity: toxicology, biochemistry and molecular biology. Amsterdam: IOS Press, 1997. p. 37-67.

SILVA, F. B.; COSTA, A. C.; ALVES, R. R. P.; MEGGUER, C. A. Chlorophyll fluorescence as an indicator of cellular damage by glyphosate herbicide in Raphanus sativus L. plants. American Journal of Plant Sciences, v.5, n.16, p.2509-2519, 2014.

STEINRUCKEN, H. C.; AMRHEIN, N. The herbicide glyphosate is a potent inhibitor of 5-enolpyruvyl shikimate acid-3-phosphate synthase. Biochemical and Biophysical Research Communications, v. 94, n. 4, p. $1207-1212,1980$.

TUFFI SANTOS, L. D.; SANT'ANNA-SANTOS, B. F.; MEIRA, R. M. S. A.; FERREIRA, F. A.; TIBURCIO, R. A. S.; MACHADO, A. F. L. Leaf anatomy and morphometry in three eucalypt clones treated with glyphosate. Brazilian Journal of Biology, São Carlos, v. 69, n. 1, p. 129-136, 2009.

TUFFI SANTOS, L. D.; FERREIRA, F. A.; MEIRA, R. M. S. A.; BARROS, N. F.; FERREIRA, L. R.; MACHADO, A. F. L. Crescimento e morfoanatomia foliar de eucalipto sob efeito de deriva do glyphosate. Planta Daninha, Viçosa, v. 23, n. 1, p. 133-142, 2005.

VELINI, E. D.; ALVES, E.; GODOY, M. C.; MESCHEDE, D. K.; SOUZA, R. T.; DUKE, S. O. Glyphosate applied at low doses can stimulate plant growth. Pest Management Science, v. 64, n. 4, p. 489-496, 2008.

VIDAL, R. A. Herbicidas: mecanismos de ação e resistência de plantas. Porto Alegre: Edição do Autor. 1997. $165 \mathrm{p}$.

Received on $16 / 11 / 2016$

Accepted on 25/10/2017

Sci. For., Piracicaba, v. 46, n. 118, p. 177-187, jun. 2018 DOI: dx.doi.org/10.18671/scifor.v46n118.04 
